Rising tide
Flash floods in
Asia prompt calls
for land reform
$p 596$

\title{
Nobel laureates spearhead effort to put Kerry in the White House
}

Geoff Brumfiel and Emma Marris, Washington

A group of high-profile researchers is to hit the campaign trail on behalf of Democratic presidential candidate John Kerry.

Planners hope that the group, known as Scientists and Engineers for Kerry, will turn researchers' anger over the Bush administration's treatment of science into a major political force. In the run-up to the election, they will attempt to recruit scientists across the country to deliver speeches on Kerry's behalf and to campaign for his election.

"It's very hard to anticipate, but I think we're going to get a very strong response," says Henry Kelly, president of the Federation of American Scientists in Washington, who is working independently from that organization to spearhead the group. Kelly, who helped put together a recent letter from 48 Nobel prizewinners endorsing the Kerry campaign (see Nature 430, 4; 2004), believes that the group of researchers will be far larger than any ever brought together on behalf of a presidential candidate.
Kelly has so far secured three Nobel laureates from across the scientific disciplines to head the group. Harold Varmus, a geneticist and former director of the National Institutes of Health, has agreed to co-chair the committee with Mario Molina, an atmospheric chemist at the Massachusetts Institute of Technology, and Burton Richter, a physicist and director emeritus of the Stanford Linear Accelerator Center in California. Others may join them.

"I have never trotted out my Nobel prize for a political campaign," says Richter. But he says recent allegations that the Bush administration has manipulated committees and worked to misrepresent and suppress academic findings have stirred him into action. "Under Bush, science is being distorted for political ends," he says.

This is not the first time that researchers have lined up behind a presidential candidate. Most recently, a 1992 group calling itself Scientists and Engineers for Clinton/Gore brought together more than

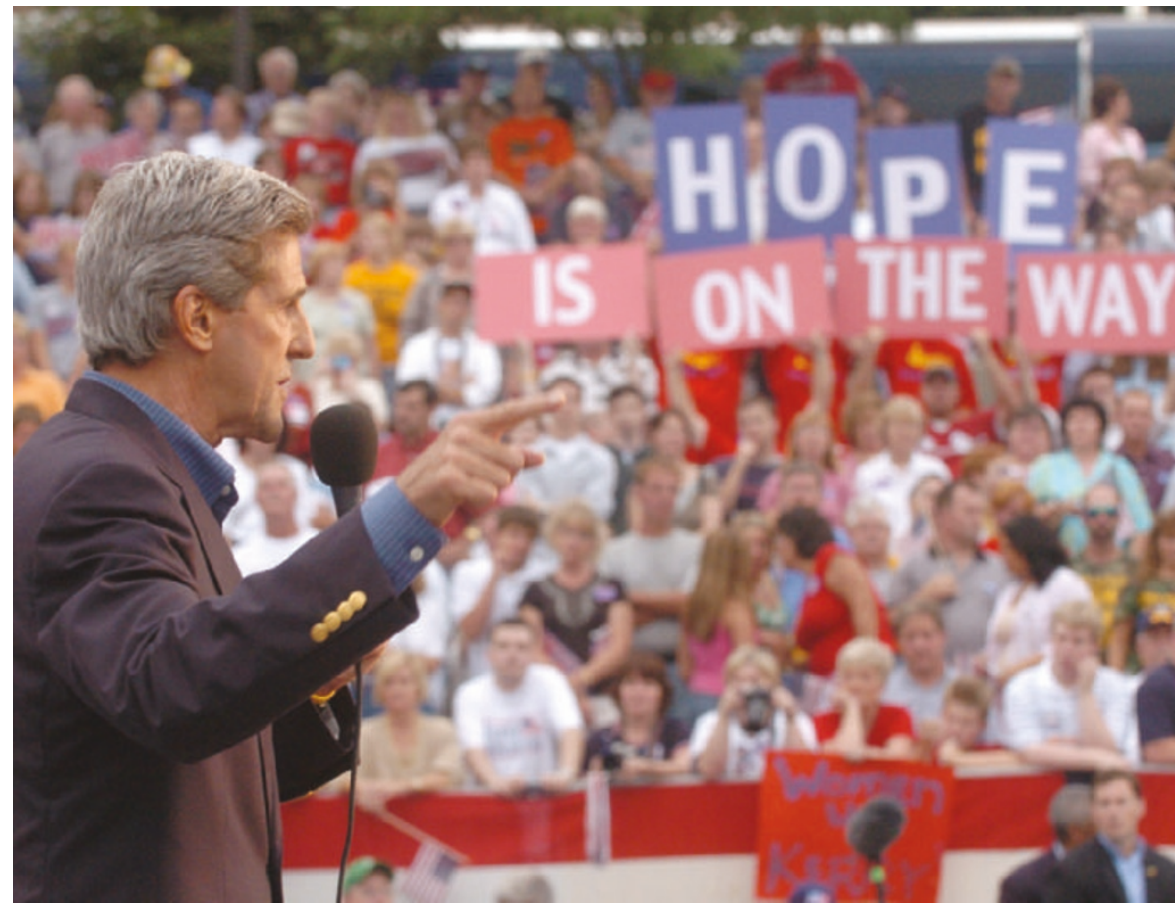

US researchers hope to make science a key issue in John Kerry's campaign to become president.
60 researchers, including 12 Nobel laureates, to endorse the then presidential hopeful. But that group met with only modest success, organizing relatively few events and meeting only once with a high-ranking member of the campaign - $\mathrm{Al}$ Gore, who was then the vice-presidential candidate.

Lewis Branscomb, a professor of public policy at Harvard University who has advised both Democratic and Republican administrations on scientific issues, says he is sceptical as to whether the new group will have an impact on the election this November. "I doubt it will amount to much," he says. Despite signing a statement by the Union of Concerned Scientists denouncing the Bush administration's treatment of science, Branscomb says he is unlikely to join the Kerrygroup.

\section{Impact factor}

David Leiter, who spent six years as Kerry's chief of staff and is currently helping in his campaign, says he is hopeful that the group will have a real impact. "The Bush administration is disinvested in science and $R \& D$ and who better to bring that to the public's attention than scientists and engineers," he says.

Already, science has taken an unusually high profile in the Kerry campaign. Kerry's wife, Teresa Heinz Kerry, mentioned the Hubble Space Telescope and the Cassini mission to Saturn in her speech at the Democratic National Convention last week.

And stem-cell research has emerged as a particularly hot issue. In his speech officially accepting his nomination as the Democrat candidate last week, Kerry asked: "What if we have a president who believes in science, so we can unleash the wonders of discovery like stem-cell research to treat illness and save millions of lives?" Ron Reagan, the son of two-term Republican president Ronald Reagan, spoke at length during the convention about the promise of stem cells and criticized Bush's policies, which limit the number of cell lines available for federally funded research.

No firm date has been set for the launch of the scientists' group, but Kelly is optimistic that it will be up and running this month. 